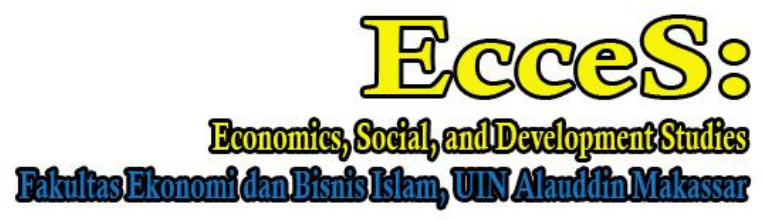

Volume 8 Number 2 Ed. December 2021: page:132-154 p-ISSN: 2407-6635 e-ISSN : 2580-5570

\title{
Indonesia Budget and Social Protections; Response to COVID-19 Pandemic
}

\section{Ecces \\ Economics Social and Development Studies}

\author{
Rizqi Haniyah ${ }^{1}, *$ \\ Fandy Anggara Putra ${ }^{2}$ \\ ${ }^{1}$ Politeknik Keuangan Negara STAN \\ ${ }^{2}$ Badan pendidikan dan Pelatihan Keuangan, Indonesia \\ E-mail: rizqi.haniyah@pknstan.ac.id* \\ (Article history) Received: 2021-11-18, Revised: 2021-12-22, Accepted:2021-12-22, \\ Available online: 2021-12-25, DOI: 10.24252/ecc.v7i1.13382, \\ Stable URL: http://journal.uin-alauddin.ac.id/index.php/ecc/index
}

\section{Abstract: Indonesia Budget and Social Protections; Response to COVID-19 Pandemic.}

This research aims to capture the government's response from the budget side facing an unprecedented health crisis. COVID-19 pandemic disrupts economic activities and negatively impacts the economy on the micro and macro scale. Data from the World Bank stated that Indonesia's poverty level increased from $9.8 \%$ to $10.2 \%$ during the first six months of the pandemic. The Government of Indonesia immediately responded to the situation by refocusing and expanding the government budget and building the stimulus package named The Covid-19 Pandemic and National Economic Recovery (PEN) to protect citizens' financial well-being and stabilize the macroeconomics condition. The expanded budget leads to the need to find the immediate resources to fulfill the budget deficits. Under the PEN program, the government supports impoverished people with social protection programs. The amount and the type of assistance were adjusted several times due to the spread of COVID-19 cases. Some problems also emerge during the implementation of the protection program, including corruption and recipient mistargeting. The government is expected to improve the program delivery mechanism and develop a system to update recipient data. Digital payment is considered the best way to deliver the benefit to the recipients in order to minimize corruption and accelerate distribution. Regarding the form of assistance, cash transfers are considered the better way to minimize corruption during the delivery process. The coordination between central and local governments should be enhanced to bring the updated data of beneficiaries.

Keywords: Budget Allocation; Burden Sharing; COVID-19; National Economic Recovery (PEN); Social Protection; 
Rizqi Haniyah, Fandy Anggara Putra, Indonesia Budget and Social Protection: Response to COVID-19 Pandemic

\section{INTRODUCTION}

WHO declared COVID-19 as the global pandemic on March 11, 2020. In Indonesia, President Joko Widodo officially announced COVID-19 as a National Disaster with Presidential Decree No 12 of 2020 on April 13, 2020. The disease was considered severe to the human respiratory system, and highly contagious airborne resulted in massive social distancing policy enforced by the government of many countries. Policies that mandate social distancing would slow the spread of the virus and force most people to work less. Before the pandemic, most economic activities involved physical interaction. Businesses that depend on social gathering and physical presence (e.g., tourism and hospitality) come to a halt, and labor-intensive manufacturing plants sharply decrease their production (Olivia et al., 2020). Furthermore, there was no clear prediction of when the pandemic and the social distancing could end.

According to the World Bank (2020b) at the global level, between 88 million-115 million people could fall back into extreme poverty in 2020 due to this pandemic, with an additional increase of between 23 million and 35 million in 2021. In June 2020, the World Bank released "Indonesia High-frequency Monitoring of COVID-19 Impacts," which described how the COVID-19 affects job and economic activities (World Bank, 2020b). This report found that $24 \%$ of households' breadwinners stopped working. Seventy-six percent of households' breadwinners continued working, two-thirds of them experienced reduced income. In April 2021, the World Bank updated its assessment and stated that the national poverty rate increased from $9.8 \%$ to $10.2 \%$ between March and September 2020, cancelling the previous three years poverty eradication progress (World Bank, 2021).

Before the pandemic, the Ministry of Finance (MoF) predicted that the national economy would grow 5.3\% in 2020, 0.18\% higher than 5.02\%, 2019 growth. After COVID19 blew the economy, MoF revised the economic growth projection in June 2020 to $0.4 \%$, then in the worst case, would be contracted by $-1 \%$. MoF also predicted that the poor people could increase by 3.02 million, up to 5.71 million in severe conditions (Kacaribu, 2020a).

The central government of Indonesia creates a comprehensive and immediate response to reallocate the 2020 budget structure to focus more on minimizing the effect of COVID-19 (Nazara, 2020). Some regulations were created to adjust the budgeting policy to respond to the negative effect of the pandemic. The first regulation, released after the government announced the first COVID-19 patient on March 2, 2020, is The Government 


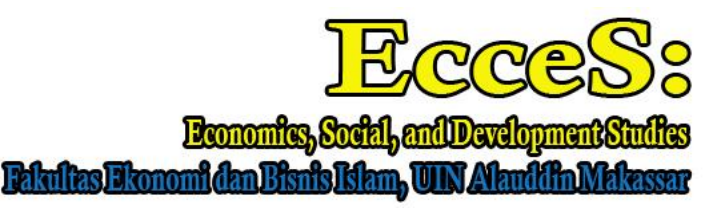

Volume 8 Number 2 Ed. December 2021: page:132-154 p-ISSN: 2407-6635 e-ISSN : 2580-5570

Regulation in lieu Acts Number 1/2020. Under this regulation, the state budget deficit was allowed to exceed $3 \%$ of the GDP until 2022. This regulation was a sign that the government was preparing to widen state spending against the threat of COVID-19.

The Ministry of Finance revised the budget postures (APBN) two times in 2020. The first revision was on April 3, 2020, with Presidential Regulation Number 54/2020, and the second revision was three months later, on June 24, 2020, with Presidential Regulation Number 72/2020, as described in Tabel 1.

Table 1 Government Budget Postures $1^{\text {st }}$ and $2^{\text {nd }}$ Revisions in 2020

\begin{tabular}{lrcrr}
\hline $\begin{array}{l}\text { Government Budget } \\
2020\end{array}$ & \multicolumn{4}{c}{ The Government Budget Revisions to Respond COVID-19 in 2020 } \\
\cline { 2 - 6 } & $\begin{array}{c}\text { Initial Budget } \\
\text { (Rp Trillion }\end{array}$ & $\begin{array}{l}\text { 1st revision } \\
\text { (Rp trillion } \\
\text { (Perpres } \\
54 / 2020)\end{array}$ & $\begin{array}{c}2^{\text {nd }} \text { revision } \\
\text { (Rp trillion } \\
\text { (Perpres } \\
72 / 2020)\end{array}$ & $\begin{array}{c}\text { \% of total } \\
\text { change }\end{array}$ \\
\hline Revenue & $2,233.2$ & $1,760.9$ & $1,699.9$ & $-23.88 \%$ \\
\hline Tax Revenue & 1865.7 & $1,462.6$ & $1,404.5$ & $-24.72 \%$ \\
\hline Non-Tax Revenue & 367 & 297.8 & 294.1 & $-19.86 \%$ \\
\hline Governemnt & $2,540.4$ & $2,613.8$ & 2739,2 & $+7.8 \%$ \\
Expenditure & $1,683.5$ & $1,851.1$ & 1975.2 & $+17.33 \%$ \\
\hline Central Governemnt & 856.9 & 762.7 & 763.9 & $-10.85 \%$ \\
\hline Local Government & $(307.2)$ & $(852.9)$ & $(1,039.2)$ & $+238.28 \%$ \\
\hline (Deficit) & $(1.76 \%)$ & $(5.07 \%)$ & $(6.34 \%)$ & \\
\hline$\%$ Deficit & & & & \\
\hline
\end{tabular}

Source: Ministry of Finance, 2020 (MoF, 2020a).

The final revision result was that the total government expenditure increased $7.8 \%$, the central government budget increased $17,33 \%$ to Rp 1,975.2 trillion, and the transfer for local government decreased $10.85 \%$, from the initial planned Rp 856.94 trillion to Rp 763.92 trillion. Unfortunately, the budget from the revenue side also revised lowers than initially

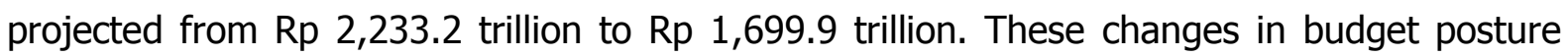
resulted in deficits soaring 3.6 times as initially planned $\mathrm{Rp} 307.2$ trillion to $\mathrm{Rp} \mathrm{1,039.2}$ trillion (MoF, 2020a).

Part of the budgets are allocated to minimize the economic impact of Covid-19 under the stimulus package named The Covid-19 Pandemic and National Economic Recovery (PEN). The government priorities focused on three main aspects: health care, economic rescue, and financial sector stabilization. In June 2020, the government finalized Rp 695.2 trillion budget for this program, increased by Rp 18 trillion from previous allocation that was Rp 677.2 trillion. However, on December 16, 2020, the official adjusted the budget for five 
Rizqi Haniyah, Fandy Anggara Putra, Indonesia Budget and Social Protection: Response to COVID-19 Pandemic

clusters inside the program to accelerate the realization of the PEN program. The detail about this reallocation is displayed in Table 2 . These budget reallocations aim at maximizing the available budget that may not be absorbed by one cluster can be utilized for other clusters.

Table 2. PEN Budget Allocation and the Realization in 2020

\begin{tabular}{lcccc}
\hline \multicolumn{1}{c}{ Clusters } & $\begin{array}{c}\text { Budgeted } \\
\text { (Rp trillion) }\end{array}$ & $\begin{array}{c}\text { Reclustered } \\
\text { (Rp trillion) }\end{array}$ & $\begin{array}{c}\text { Realization } \\
\text { (Rp trillion) }\end{array}$ & $\begin{array}{c}\% \\
\text { Realization }\end{array}$ \\
\hline Social Protection & 203.9 & 230.2 & 216.6 & 94.1 \\
\hline SMEs support & 123.46 & 116.3 & 112.3 & 96,56 \\
\hline Busines Incentives & 120.61 & 120.61 & 58.4 & 48.42 \\
\hline $\begin{array}{l}\text { Sectoral and regional } \\
\text { Government }\end{array}$ & 106.11 & 67.86 & 65.2 & 96,08 \\
\hline Health & 87.55 & 99.5 & 62.6 & 62.91 \\
\hline Corporate Financing & 53.57 & 60.73 & 60.73 & 100 \\
\hline Total & 695.2 & 695.2 & 575.8 & 82.83 \\
\hline
\end{tabular}

Sources: Ministry of Finance 2021 (MoF, 2021)

The reclustering between sectors in the PEN program also promotes flexibility and responsiveness in accommodating the public support needs based on dynamic and uncertain conditions during COVID-19 (MoF, 2021). Sri Mulyani, the Minister of Finance of Indonesia, in the webinar on July 7, 2021, titled Mid-Year Economic Outlook 2021, emphasized that due to the dynamic Covid-19 conditions, they often faced challenges where existing plans had to change because the plan did not work in this coronavirus pandemic era (Bisnis Indonesia, 2021). She gave an example about the PEN budget for health sector. It was expected that at the end of 2020, the government would start the vaccine procurement, so it was budgeted at Rp. 97.9 trillion for the health sector. Afterward, it shifted to 2021. Thus, PEN spending for the health sector in 2020 focused on labor incentives and medical equipment and facilities, building hospitals, and the Covid-19 Task Force budget.

Table 2 revealed that one-third of the PEN fund in 2020 was in the form of social protection. This cluster was expected to increase the national demand-side and stimulate the economic growth. Ministry of Finance emphasized that the social protection under PEN has prevented the deepening fall in economic growth. The contraction of GDP 2020 on Q2 was $5.3 \%$. the decrease was in line with the drop of government spending, which included for social protection, by $-6.9 \%$ (YoY) in the same quarter. The GDP contraction improved to 3.5\% (YoY) and 2.2\% (YoY) in Q3 and Q4 (MoNDP, 2020a). The Ministry of Financed claimed that the social protection programs effectively restrain the decline in household 
consumption. In the Q4 2020, the household consumption was contracted 3.6\%. Without social protection, household consumption might be contraction by $5 \%$ or more (MoF, 2021).

Indonesia was among the top ten countries with the largest recipients of cash transfer programs, below the United States, Japan, Pakistan, Philippines, Brazil, and China. Also, in terms of the percentage of total recipients from the total population, Indonesia's cash transfer program was estimated to reach $13.7 \%$ of the population in 2020 . On average, $16 \%$ of the world population receive cash transfer assistance from their governments (Gentilini et al., 2020).

Governments worldwide share the same challenges in distributing the social protection program to the beneficiaries, including lack of data on potential beneficiaries in the informal sector, poor public finance management (PFM) information systems, and a low level of preparedness to respond to significant economic shocks (Una et al., 2020). These conditions push the governments to face a difficult trade-off between adopting tight or loose eligibility requirements. A tight eligibility requirement would ensure that the programs serve the right people but increase the risk of delaying the distribution of the assistance and excluding some eligible people. Loose eligibility criteria would widen the number of beneficiaries and faster the delivery process, but it needs a larger amount of budget and increase the risk of fraud (Una et al., 2020). It is crucial to be mindful of vulnerabilities to misuse and corruption to ensure the effectiveness of the expenditure. A large scale of government spending would raise incentives for rent-seeking behavior and uncoordinated action between many actors that would increase the possibility of inefficiency and leakage (Khasiani et al., 2020). In the perspective of creating fiscal space to finance government programs, the crisis also pushes the government to establish a different institutional framework to allow fast and effective decision-making during the budget process (Jõgiste et al., 2012).

This research focuses on how the Government of Indonesia managed the social protection program to respond to the outbreak of COVID-19 that relates to the budget reallocation, financing mechanism to meet the budget deficit, and the risk that emerges due to the large scale of the program. This paper also discusses the trade-off between the type of social assistance, the quality of beneficiary data, and the incidence of fraud. Its also explored the imperfection in the budget execution for the social protection program, which 
Rizqi Haniyah, Fandy Anggara Putra, Indonesia Budget and Social Protection: Response to COVID-19 Pandemic

accounted for $33.3 \%$ of The Covid-19 Pandemic and National Economic Recovery (PEN) fund.

\section{LITERATUR REVIEW}

The government budget is the fiscal policy tool that consists of the estimation of taxes revenue and government spending over a specific future period to influence economic activities in desired ways. Governments typically use fiscal policy to promote sustainable and robust growth and to reduce poverty. The role and objectives of fiscal policy gained prominence during the recent global economic crisis, when governments stepped in to support financial systems, jump-start growth, and mitigate the impact of the crisis on vulnerable groups (Horton and El-Ganainy, 2020).

The crisis usually shrinks GDP growth and affect social and economic condition such as reduced trade, increased unemployment and job uncertainty, and growing social unrest. Studies from the past crisis evidence show that poorly managed crises, in the long-term, can harm the economy by increasing poverty, creating long-term unemployment, and reducing growth potential. The countries might respond to the situation by increasing their expenditure due to the availability or willingness to use capital. Alternatively, they could implement the fiscal discipline due to the unavailability of the fiscal space or worry about the impact of high post-crisis borrowing costs (Premchand, 1983). Countries that have avoided fiscal discipline adopt expansionary policies during past crises have typically been more successful (Horton and El-Ganainy, 2020).

According to (Boin et al, 2017), a crisis is a label used to characterize situations regarded as extraordinary, volatile, and potentially far-reaching in negative implications. They found that crises occur when the core values or life-sustaining systems of a community come under threat. Also, crises happen when shared values such as safety and security, welfare and health, integrity, and the rule of law become shaky or meaningless due to violence, destruction, damage, or other forms of adversity.

The coronavirus crisis, emerged in 2019 , is the first and foremost a public health threat, but it also becomes an economic threat. The shock triggered the world economic recession and the economic growth was predicted to reach the recessionary threshold, below 2.5\% (UNCTAD, 2020). The IMF and World Bank emphasized that social protection expenditure is a pillar of counter-cyclical economic policy by delivering immediate financial support to those in need while crises happen. As crisis hits, providing resources to those 
who need them will directly protect them and support the overall economy. Based on the experience of the greatest threat since the 2008 financial crisis, the importance of countercyclical economic policy cannot be overstated (UNICEF, 2020).

At the beginning of the COVID-19 pandemic, the governments were challenged to create a comprehensive and immediate response to reallocate the budgets to reprioritize public spending toward bolstering the economy, the health system, and the highly affected sectors (Barroy et al., 2020). By reprogramming existing budgets, activating contingency reserves, adopting supplementary budgets, and creating dedicated COVID-19 extrabudgetary funds to further mobilize resources and accelerate emergency spending (Rahim et al., 2020). Intervention measures should be timely, targeted, and temporaryquickly reversed once conditions improve (Horton and El-Ganainy, 2020). In Corona cases, the government might need to speed up with which interventions are identified and implemented, which could result in relaxed controls, poor or non-existent targeting, and unclear or unenforceable eligibility criteria for support (Khasiani et al., 2020).

According to (Khasiani et al., 2020), based on the experience of the Ebola virus disease outbreak in 2014 until 2016, the need for speedy implementation does not require abandoning the controls. Instead, the controls should be adapted and streamlined to ensure timeliness without compromising safeguards. Budget execution should be conducted within the prevailing legal framework, following good practices and activating emergency provisions. All transactions, including non-cash transactions and transactions supported by development partners, should be recorded to facilitate comprehensive monitoring and reporting. Lastly, an adequate audit trail should always be maintained to enable external post-assessment and evaluation (Khasiani et al., 2020).

\section{METHODS}

This research was conducted using a qualitative approach with library research. The data and information were collected from various digital resources from reports, journals, scientific articles, and e-books. This research started with questioning how Indonesian government policy action toward the unprecedented calamity COVID-19, especially its budget response. After examining the refocusing and reallocation of the government budget, the research discusses the National Economic Recovery Program (PEN), specifically on the social protection cluster as part of the PEN program and its implementation. 
Rizqi Haniyah, Fandy Anggara Putra, Indonesia Budget and Social Protection: Response to COVID-19 Pandemic

This research uses data such as the government budget and the realization, the budget for PEN, and the allocation for Social Protection programs, especially for the first year of COVID-19. The data was collected from the news, bulletin, and report published by the Ministry of Finance website (www.kemenkeu.go.id). The data on Indonesia's economic outlook were obtained from the periodic report by the Ministry of National Development Planning (MoNDP), Statistic Indonesia (BPS), the Ministry of Finance (MoF), and some international organizations such as World Bank and the IMF.

\section{RESULT AND DISCUSSION}

\section{A. Budget (APBN) Revision in 2020 in Response to Covid-19}

Due to the economic contraction, the low tax collection exacerbates the challenges of financing the expanded expenditure to respond to COVID-19. The MoF projected that government revenue from tax and non-tax resources would decrease from almost $12 \%$ of the GDP in 2017 and 2018 to less than 10\% in 2020 (Olivia et al., 2020). To minimize the fiscal burden in the 2020 Budget, the central government reallocated it to focus more on the vital function against COVID-19.

Table 3. The Central Government Budget Revision to Respons COVID-19 2020

\begin{tabular}{lrrrr}
\hline \multicolumn{1}{c}{ Budget Function } & $\begin{array}{c}\text { Initial } \\
\text { Budget (Rp } \\
\text { trillion) }\end{array}$ & $\begin{array}{c}\text { Revised } \\
\text { Budget } \\
\text { (Rp trillion) }\end{array}$ & $\begin{array}{c}\text { Change } \\
\text { (Rp trillion) }\end{array}$ & \% of change \\
\hline Public Service & 475 & 757.98 & 282.98 & $59.57 \%$ \\
\hline Defence & 131.25 & 117.96 & -13.29 & $-10.13 \%$ \\
\hline Public Order and Security & 162.73 & 141.28 & -21.45 & $-13.18 \%$ \\
\hline Economy & 406.17 & 435.97 & 29.8 & $7.34 \%$ \\
\hline Environment & 18.36 & 13.91 & -4.45 & $-24.24 \%$ \\
\hline $\begin{array}{l}\text { Housing and Public } \\
\text { Facilities }\end{array}$ & 30.36 & 20.65 & -9.71 & $-31.98 \%$ \\
\hline Health & 61.15 & 81.62 & 20.47 & $33.48 \%$ \\
\hline $\begin{array}{l}\text { Tourism and Creative } \\
\text { Economy }\end{array}$ & 5.06 & 3.06 & -2 & $-39.53 \%$ \\
\hline Religion & 10.09 & 9.68 & -0.41 & $-4.06 \%$ \\
\hline Education & 156.89 & 142.43 & -14.46 & $-9.22 \%$ \\
\hline Social Protection & 226.42 & 250.7 & 24.28 & $10.72 \%$ \\
\hline Total & $1,683.48$ & $1,975.24$ & 291.76 & $17.33 \%$ \\
\hline Sources: Ministry of Finance & & & & \\
\hline
\end{tabular}

Sources: Ministry of Finance and House of Representatives (MoF, 2020; Zahara et al., 2021)

In 2020, the government increased the expenditure for public service, economy, health, and social protection. On the other hand, the government lowered the expenditure 
budget for defense, public order and security, environment, housing and public facilities, tourism and creative economy, religion, and education.

In the defense sector, the government reduced the expenditure budget for the military and only focused more on the prioritized equipment of the defense system, such as ships and jets (Gumilang, 2020). The purchasing of ships was considered necessary due to increasing tension in the South China Sea. The reduced budget did not affect the troops and employes' salaries and wages but the non-salary expenditures such as inter-regional visits or international activities (Halim, 2020).

The government also reduces expenditure budget for education and the environment sector. In the education sector, the significant decrease came from the Ministry of Research and Technology, whose budget fell from Rp 42 trillion to Rp 2 trillion, decreasing by 95\%. The government eliminated some programs in education function, such as the national exam for elementary and primary school graduates and in-person seminars and dissemination to reduce the budget and curb the virus spread (Ayu, 2020). In the environmental sector, the government minimized in-person activities and inter-regional transportation, focusing more on the activities that contribute to the ongoing concerns of forestry entrepreneurship, conservation visits, and social forestry (Zhacky, 2020).

Even though there were some budget reductions on some sectors, the government still had to find resources to finance the deficits. The government created a burden-sharing program between the Ministry of Finance and the Bank of Indonesia to provide adequate, low-interest costs and more certain financing resources. The certainty that the government obtains sufficient revenue through a burden-sharing mechanism is higher than if the government issue bonds in the regular obligation market (Hidayat, 2020).

Before 2020, the Indonesian government must maintain a deficit below $3 \%$ of the GDP as stated in the law number Act Number 17/2003. Issuing The Government Regulation in Lieu of Acts Number 1/2020, the Indonesian government allows to widen the fiscal deficit from $1.76 \%$ in the initial 2020 budget to $5.07 \%$ in the first revision, as mentioned in Presidential Regulation Number 54/2020, then to $6.34 \%$ in the second revision as mentioned in Presidential Regulation Number 72/2020.

The regulation also mentions some financing resources that the government can access to finance the COVID-19 response programs. The sources mentioned are the remaining budget funds from the previous fiscal year (SILPA); endowment and accumulated 
funds for education development; funds controlled by the government with specific criteria; funds controlled by the Public Service Agency (BLU); and the reduction of state's capital contribution in the State-Owned Enterprises. This regulation also allows the government to issue special-purpose bonds that can be bought by the Indonesian Central Bank, stateowned enterprises, corporation investors, and retail investors.

\section{Burden-Sharing Program as Domestic Resources for Budget Deficit}

Based on the Government Regulation Number 23/2020, the Ministry of Finance (MoF), as the fiscal authority, and the Indonesian Central Bank (BI), as the monetary authority, create a burden-sharing mechanism, a newly implemented policy, as the domestic debt resources to issued stimulus the COVID-19 effect and to funding the National Economic Recovery Program (PEN). This new scheme called "the burden-sharing" mechanism, built an agreement that Central Bank (BI) is always ready to buy the government's special purpose bond if it cannot be fully absorbed by the primary market (Nazara, 2020).

The Burden Sharing program applies for the 2020 Fiscal Year and will continue depending on the financing necessities in the future year (MoF, 2020b). This decision led to a meager additional foreign loan compared to the domestic's issued for 2020. Compared to the Asian currency crisis, Indonesia has much stronger resilience to external shocks, with improved fundamentals and systems like lower dependency on external debts and accumulation of foreign exchange reserves (Fukuchi, 2020).

The burden-sharing program is divided into three mechanisms based on the purposes of using the money. There are public goods benefits; non-public goods/benefits (SMEs) and corporations; and other non-public goods benefits. The financing for public goods/benefit provision consists of financing in for health, social protection, and other related expenditures in the line of ministry and local governments. The funding for public goods/benefits will be paid entirely by the BI through government bond private placement. The level of the interest rate is equal to the BI's reverse repo rate, and the BI will return the interest to the government once it is paid in the future (MoF, 2020b).

The financing for non-public goods/benefit provision includes financing for micro, small, and medium business entities (MSME), non-MSME corporation, and other non-public goods. For the non-public goods/benefit provision, the government covers the fund by issuing bonds to the market, and BI will contribute as big as the difference between the market rate and BI's reverse repo rate minus $1 \%$. Meanwhile, for other non-public 


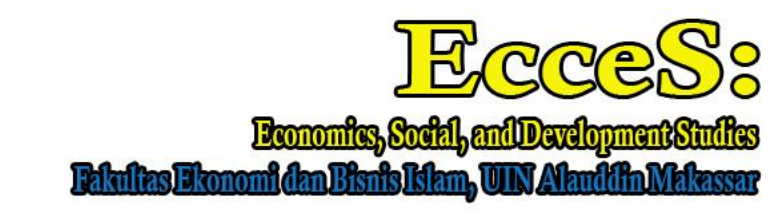

Volume 8 Number 2 Ed. December 2021: page:132-154 p-ISSN: 2407-6635 e-ISSN : 2580-5570

goods/benefits, the government will pay the cost of financing to BI based on the market rate (MoF, 2020b).

Based on the Financial Report of Central Government 2020, the realization of the shortfall expenditure in 2020 was Rp 947.70 trillion, and the government liabilities increased Rp1.193.29 trillion. Reported in the Central Government Financial Report of 2020, the deficit realization was $6.14 \%$ as seen in Table 4.

Table 4. The Government Budget and Realization Year 2020

\begin{tabular}{lrrr}
\hline $\begin{array}{c}\text { Government Budget } \\
\text { Realization) }\end{array}$ & $\begin{array}{c}\text { Budget 2020 } \\
\text { (Rp trillion) }\end{array}$ & Realization 2020 & \% Realization \\
\hline Revenue & $1,699.9$ & $1,647.8$ & \\
\hline Governemnt Expenditure & 2739,2 & $2,595.5$ & \\
\hline (Deficit) & $(1,039.2)$ & $(947.7)$ & \\
\hline$\%$ deficits & $6.34 \%$ & $6.14 \%$ & $114.83 \%$ \\
\hline Financing (net) & $1,039.2$ & $1,193.3$ & \\
\hline SILPA & & 245.6 &
\end{tabular}

Source: The Ministry of Finance (MoF, 2021)

The financing fund mainly was obtained from domestic resources totaling Rp 1.146.81 trillion and a very small amount of foreign resources, Rp46.48 trillion. Under the burden-sharing program, the Indonesian government obtained Rp75.86 trillion on the first agreement and Rp 674.59 trillion, on the second agreement consists of Rp 397.56 trillion for public goods/benefit, and Rp 117.03 trillion for non-public goods/benefit (MoF, 2021). From 2020 realization, the government has Rp 245.6 trillion SiLPA.

There is some issue following up this policy, including the impact on Indonesia's credit ranking. Some international credit ranking agencies have responded to this issue. Moody's-Investor Services (Moody's) report that, in the short term, Indonesia's burdensharing policy would not affect the country's sovereign ratings. However, they warned that it might affect the central bank's credibility and its ability to ensure price stability (Akhlas, 2020). Moody's gives Indonesia (low-moderate risk of default) rating and its outlook remains stable. Another international credit rating, Fitch, affirms that Indonesia's BBB (low risk of default) credit ranking also remains stable. The report claimed that the burden-sharing program would reduce the government's direct interest cost and unlikely generate inflation since there is a demand compression during the crisis. The potential drawback will emerge if 
Rizqi Haniyah, Fandy Anggara Putra, Indonesia Budget and Social Protection: Response to COVID-19 Pandemic

the burden-sharing policy goes beyond 2020 since it would undermine investor confidence (Fitchratings, 2020).

\section{B. Social Protection Budget in Response to COVID-19}

The IMF and World Bank emphasized that social protection expenditure is a pillar of counter-cyclical economic policy by delivering immediate financial support to those in need while crises happen (UNICEF, 2020). The Indonesian government expanded the social protection program to minimize the economic costs of COVID-19, especially designed for people who are already below the poverty line, and those potentially fall back into poverty.

Table 5 Budget and Realization of the Social Protection Program under the PEN

\begin{tabular}{|c|c|c|c|c|c|}
\hline \multirow[b]{2}{*}{$\begin{array}{l}\text { Social Protection } \\
\text { Programs }\end{array}$} & \multicolumn{5}{|c|}{ Social Protection Budget and realization for the year 2020} \\
\hline & $\begin{array}{l}\text { Coverage } \\
\text { realization }\end{array}$ & $\begin{array}{l}\text { Initial } \\
\text { Budget } \\
\quad(\mathrm{Rp} \\
\text { trillion) }\end{array}$ & $\begin{array}{l}\text { budget } \\
\text { under } \\
\text { PEN } \\
\text { (Rp } \\
\text { trillion) }\end{array}$ & $\begin{array}{l}\text { Reclusterred } \\
\text { on Dec } 16^{\text {th }} \\
\text { (Rp trillion) }\end{array}$ & $\begin{array}{c}\text { Realizatio } \\
\text { n (Rp } \\
\text { Trillion) }\end{array}$ \\
\hline $\begin{array}{l}\text { Conditional Cash } \\
\text { Transfer Program }\end{array}$ & $\begin{array}{r}10 \text { million } \\
\text { household }\end{array}$ & 29.1 & 37.40 & 41.97 & 41.94 \\
\hline $\begin{array}{l}\text { Cash Transfer (Non } \\
\text { Jabodetabek) }\end{array}$ & $\begin{array}{r}9 \text { millon } \\
\text { household }\end{array}$ & - & 32.40 & 33.61 & 32.60 \\
\hline $\begin{array}{l}\text { Village Fund Cash } \\
\text { Transfer }\end{array}$ & $\begin{array}{r}11 \text { million } \\
\text { household }\end{array}$ & - & 31.80 & 31.80 & 23.74 \\
\hline Basic Food Voucher & $\begin{array}{l}20 \text { million } \\
\text { household }\end{array}$ & 28.1 & 43.60 & 46.20 & 43.90 \\
\hline $\begin{array}{l}\text { Basic Food Social } \\
\text { Assistance } \\
\text { (Jabodetabek) }\end{array}$ & $\begin{array}{l}1.9 \text { million } \\
\text { household }\end{array}$ & - & 6.80 & 7.00 & 7.09 \\
\hline Basic foods allowance & - & - & 25.00 & - & - \\
\hline Electricity Subsidy & $\begin{array}{r}31.2 \text { million } \\
\text { house }\end{array}$ & - & 6.90 & 11.54 & 11.45 \\
\hline Pre-work card & $\begin{array}{r}5.6 \text { million } \\
\text { persons }\end{array}$ & 10 & 20.00 & 20.00 & 18.25 \\
\hline Wage Assistance & $\begin{array}{c}12.4 \text { million } \\
\text { persons }\end{array}$ & - & - & 29.78 & 29.5 \\
\hline $\begin{array}{l}\text { Wage Subsidy } \\
\text { Assistance for non- } \\
\text { permanent teachers }\end{array}$ & $\begin{array}{c}2.6 \text { million } \\
\text { persons }\end{array}$ & - & - & 4.21 & 4.07 \\
\hline Internet Quota Subsidy & $\begin{array}{l}51 \text { million } \\
\text { persons }\end{array}$ & - & - & 4.09 & 4.06 \\
\hline Total & & & 203.90 & 230.20 & 216.60 \\
\hline
\end{tabular}

Sources: Ministry of Finance, the year 2020 and 2021 (Processed by Author)

In May 2020, the government established Rp 203.9 trillion budget for social protection to respond to COVID-19 2020. Then the budget increased in December 2020 to Rp 230.2 trillion, and its realization was Rp 216.6 trillion. Social protection programs need to 
be comprehensive, well-managed, and adaptable to adjust to the growing number of people in poverty affected by COVID-19 (Olivia et al., 2020).

Table 5 shows that some social protection such as conditional cash transfer program, basic food voucher, and pre-work card program existed before the pandemic. The government created new other programs in 2020 to respond the pandemic, including cash transfer, basic food assistance and allowance, and electricity subsidy. In December 2020, the government eliminated the basic foods allowance program and replaced it with other program: Wage Assistance, Wage Subsidy Assistance for non-Permanent Teachers, and Internet Quota Subsidy (MoF, 2021).

These are the description of the form of social protection programs to respond to the COVID-19 in 2020:

\section{Conditional Cash Transfer Program}

Program Keluarga Harapan (PKH) is a social program to encourage poor and vulnerable families to access health and education services, especially for pregnant women and children. There are three groups of recipients entitled to this program. It is based on their health, education, and social welfare conditions. Under the health criteria, the targeted families include pregnant women, breastfeeding mothers, or children between zero to six years old. Under the education criteria, the program beneficiaries are families with children who are in K-12 educational institutions. A family with children aged 6 to 21 years who have not finished their $\mathrm{K}-12$ education includes the education criteria. The social welfare criteria include families with elderly members aged 60 years or older or family members with a disability.

\section{Cash Transfer - (Non-Jabodetabek; Village Fund Cash Transfer)}

The poor and vulnerable families living outside Jakarta and the urban area around Jakarta benefited from cash transfer programs from PEN. Nine million households received Rp 600 thousand from April to June 2020 and Rp 300 thousand from July to September 2020. This program focused on the bottom $50 \%$ group and aimed to maintain the society's purchasing power affected by the pandemic (Oktari, 2020). This program excluded the beneficiaries of Conditional Cash Transfers and Basic Food vouchers.

Citizens who live in the village get a similar amount of money through the Village Fund Transfer Program. This program was delivered to the village administration and forwarded to the recipient. The benefit size was similar to the Non-Jabodetabek cash 
transfer that gave its beneficiaries Rp 600,000 from April to June 2020 and decreased to Rp300,000 from July to September 2020. The list of beneficiaries of this program is determined by the Head of Village based on guidelines set by the government through the Ministry of National Development Planning (MoNDP). The recipients were poor or vulnerable families who do not get other government beneficiaries (MoNDP, 2020b).

\section{Basic Food Voucher}

The Basic Food Voucher is intended for vulnerable families who are not included in the beneficiaries of the Cash Transfer Program. Considering above 30\% of households faced food insecurity during this pandemic. The Basic Food Voucher improves household's access to this benefit. The benefit increased from Rp 150,000 to Rp 200,000 per month. This program provides a non-cash card issued by government banks to the beneficiaries selected based on the Ministry of Social Affairs (MoSA) data (MoF, 2020c). The recipients can use the card to buy staple food in the store that the government has appointed. The MoSA manages the data collection of potential beneficiaries of this program. Local governments verify the recipient data that the MoSA has collected. The verified recipient got a bank debit card that contained money in the amount stipulated by the government.

\section{Basic Food Assistance - Jabodetabek}

During the COVID-19 pandemic, poor and vulnerable households who live in Jakarta and the urban area Jakarta, Bogor, Depok, Tangerang, and Bekasi (Jabodetabek) have received Basic Food Assistance. The benefit from April to June 2020 was Rp 600,000 and decreased to Rp300,000 for July through September 2020. In June 2020, the government decided to expand this program until December 2020 (Bardan, 2020). The benefit was delivered in the form of goods containing ten basic food items such as rice, eggs, meat, sugar, milk, etc. The priority beneficiaries of this program included laborers, informal workers, retail store owners, and taxi drivers. This program excluded the beneficiaries of Conditional Cash Transfers and Basic Food vouchers.

\section{Electricity Subsidy}

The objective of the electricity subsidy program is to cover the electricity expenditure for electricity customers who use 220 to 1,300 Volt Ampere (VA) of electricity power. Customers in the 220 to 450 VA obtained a $100 \%$ subsidy, and customers in the 900 VA get a $50 \%$ subsidy. Customers who use 1,300 VA only have to pay their minimum payment fee, so they pay according to actual usage during a month. Twenty-four million households 


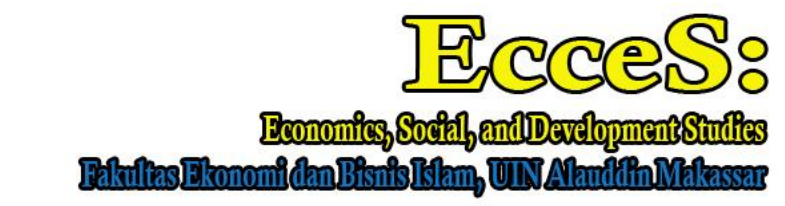

Volume 8 Number 2 Ed. December 2021: page:132-154 p-ISSN: 2407-6635 e-ISSN : 2580-5570

benefit from fully subsidized electricity bills, and 7.2 million families receive a $50 \%$ discount on their electricity (Ramli, 2021).

\section{Pre-work Card}

The pre-work card is an unemployment benefits program converted to a semi-social protection program during the COVID-19 pandemic. The principle of this program is to improve the job seeker's capacity through training in which the program covers the training fee. Every citizen aged 18 years and older who is not studying in a formal education institution has a right to become a recipient of this program. During the COVID-19 pandemic, this program focused on unemployed or temporarily unemployed people who furloughed by their employer. The total benefit of the card is $\mathrm{Rp} 3.5$ million per recipient and will cover 5,597,183 recipients in 2020 (CMEA, 2020). The recipients included women, people with disabilities, low-educated people, senior citizens, and ex-migrant workers. The benefit is divided into three forms: Rp 1 million is for training, Rp 2.4 million is a cash transfer for four months installment, and Rp 0.15 million is a cash incentive for completing three evaluations and program evaluation surveys.

\section{Wage Assistance (for Worker and non-PNS Educators)}

The objective of the subsidy is to provide subsidy to the worker that might be experiencing reduced salary/ wages affected by COVID-19. The beneficiaries were the employee with active participants of the Employment Social Security program (BPJS Employment) who paid dues until June 2020 and got salaries below Rp 5 million, based on the latest salary reported by the employer. The beneficiary received Rp 600,000 for four months disbursed in 2 stages and transferred directly to their bank account (MoF, 2021).

Wage Assistance distribution was expanded to non-permanent (non-PNS) educators and staff under the Ministry of Religion and the Ministry of Education and Culture (Kemendikbud). The assistance is entitled to teachers, lecturers, and non-PNS education staff (librarian, laboratory staff, and administration staff). This program was emerged after considering that the non-permanent teachers of public school salaries were below Rp 5 million; not all of them were registered on BPJS Employment. The beneficiary received Rp 600,000 for three months and transferred it directly to their bank account (MoF, 2021).

\section{Internet Quota Subsidies}

The government has budgeted a total of Rp 7.21 trillion for quota subsidies for all students, teachers, and lecturers for the next four months for Distance Learning (PJJ) due to 
Covid-19. The quota subsidy will be given for four months from September to December 2020 at 35GB per month for 39.78 million students and 50GB per month for 8.24 million students. Teachers and lectures received 42GB and 50GB per month, respectively. The distribution mechanism of internet data quota assistance based on data collection from Main Education Data (Dapodik/Data Pokok Pendidikan). And then the Ministry of Education and Culture conducted verification and validation of mobile phone numbers by mobile operators before the internet quota distributed (MoEC, 2021).

To conclude, budgeting in the crisis, especially for the social security program, is challenging due to the uncertainty around the economic outlook (Curristine et al., 2020). The uncertainty and absence of precedence information about the COVID-19 case in Indonesia made the government constantly adjust the programs to match the pandemic situation. Including how to and what best programs match the needs of the society in the pandemic era. In terms of social protection, ideally, the allocation should affect the targeted aim; the benefits to be delivered should match the society's needs; the recipient should meet the criteria targeted in the programs.

\section{Issues And Recommendation Related Social Protection Implementation}

The COVID-19 pandemic has resulted in countries ramping up spending and contingent spending to address urgent needs related to saving lives and livelihoods. To convince the spending would be effective, it is crucial to be mindful of the vulnerabilities to potential misuse and corruption. The social protection program needs to expand horizontally to cover non-regular program beneficiaries affected by a shock and vertically to protect existing beneficiaries who may need increased benefits in times of need (Gentilini et al., 2020). There are several problems in the social budget implementation.

\section{Corruption}

In December 2020, the Minister of Social Affairs was accused of taking cash from contractors supplying basic food assistance to people in Jakarta and the surrounding urban area. Anti-corruption agents found evidence of the corruption by discovering more than Rp 14.5 billion filled in a suitcase and other containers. The Minister was allegedly offered Rp 10,000 in kickbacks per Rp 300,000 food parcel provided by two contractors.

The Minister managed the procurement for this program through direct procurement. In the procurement process, the food assistance providers negotiated the amount of money that they could give in a kickback to win the contract (KPK, 2020). The food assistance 
program could not use regular auction procurement due to the short time range to execute the program (Fahlevi, 2020).

During the crisis, the government faces a dilemma in executing their budget, especially in social protection programs. They need more flexibility to use their budget to accelerate the distribution process. The supervision over the budget execution process should be managed carefully to ensure the accountability of the procurement and distribution process. In Indonesia, each ministry has an internal audit unit responsible for ensuring the business process complies with the norms and regulations. However, the corruption in the Ministry of Social Affairs indicates that the internal audit process might not perform properly.

The government should adjust the budget monitoring process and redesign the delivery of social assistance programs. Based on the whistle-blower monitoring system, more than 100 cases of misappropriation of social protection funds are currently under investigation by law enforcement agencies (Alfedo and Azmi, 2020). The government needs to comprehensively publish detailed information about the ongoing social assistance program such as the criteria of the recipient entitled, how, and what the recipients will get (Alfedo and Azmi, 2020). This information is important to incorporate social control during the distribution process. In terms of delivery methods, the utilization of digital payment is proven to make the distribution process faster and less corrupt (Hanna and Olken, 2020a).

In terms of social protection program monitoring, there is a need to incorporate society and local government. The central government has decided that the social protection program should be delivered in the form of cash transfers. In addition, the information about the social protection benefit informed broadly to society about social protection detailed information. Based on this information, society can report to the government if there is a reduction in the amount of money they get. The President has announced no transaction fee borne by the recipient (Coordinating Ministry for Human Development and Culture, 2021).

\section{The Accuracy of the Beneficiaries}

The distribution of social protection programs faces a challenge related to the accuracy of the program recipients. This situation is a trade-off from the need to execute this program timely to minimize the economic impact of COVID-19. According to (Noerkaisar, 2021), based on a survey held by Saiful Murjani Research and Consulting 
Rizqi Haniyah, Fandy Anggara Putra, Indonesia Budget and Social Protection: Response to COVID-19 Pandemic

(SMRC) of 1,235 people held on May 2020, 96\% of the respondents were aware that the government has some ongoing social assistance programs. There are $49 \%$ of respondents said the programs were mistargeted. $60 \%$ of them said it was mistargeted because there are recipients did not receive the social assistance even though they are entitled. $29 \%$ thought the social assistance gave to wrong person, and $4 \%$ responded that the amount of social assistance provided is too small.

The targeting process is prone to inclusion and exclusion errors. In terms of inclusion errors, there are parts of society that return the assistance to the government since they no longer feel like they are in a situation to benefit from the program (Teja, 2020). In Indonesia, the exclusion error is bigger since the informal sector is larger than the formal sector. There are $88.57 \%$ of workers in the agricultural sector and $48.57 \%$ of workers in the non-agricultural sector worked in the informal sector (Statistics Indonesia, 2020a, 2020b). There is also a problem related to the fluctuation of the total of the recipients, especially in Basic Food Assistance - Jabodetabek Program that reflects data inaccuracy and the government does not have a proper mechanism to update and improve the beneficiary data (Kacaribu, 2020b).

The targeting error will be minimal if the government widens and increase the number of program recipients (Hanna and Olken, 2020a). However, cooperation between central and local governments should be enhanced in the process of updating and synchronizing the data of the population. This effort is a great investment to make the distribution of social protection programs while COVID-19 and afterward accurately reach the target.

\section{Benefit Adequacy}

Based on the implementation in 2020, Indonesia's social protection program still has some problems related to benefit adequacy (Kacaribu, 2020b). For example, the beneficiaries of the Conditional Cash Transfer program felt that the cash receipt is inadequate to cover their monthly expenditure. The recipients of the Food Assistance Program also reported the same problem: the benefit can only support their daily needs for up to two weeks. They also need more variety and better-quality food products. Considering these evaluations and the uncertainty of economic conditions, the government needs to expand the social protection program to reach more recipients and increase the size of the benefit. 
One of the breakthroughs the government can try to make the social protection program more efficient is connecting the size and coverage of the program in each region with region-specific health or lockdown measures (Hanna and Olken, 2020b). For example, in Indonesia, the social protection policy can be tied to the green, yellow, orange, red categories of the COVID-19 health situation. The later and darker color reflects the level of COVID-19 severity in the area. Therefore, when a region faces more severe health and lockdown situations, it would automatically increase the size and coverage of the program related to that specific area.

\section{CONCLUSION}

Unpredicted global pandemic pushes the countries, including Indonesia, to turn the priority of government spending. Despite the need for more funds to minimize and anticipate the economic effect caused by the turndown of the economics, the national revenue also decreased. The Indonesia government national budget deficit was inclined from originally planned $1.76 \%$ of GDP, then realized at $6.14 \%$ of GDP. Due to the limitation of the revenue source, the Indonesia government with Bank of Indonesia build a burdensharing agreement scheme to finance the budget deficit as the domestic funding resources and minimize the extreme additional increase of foreign debt.

The Indonesian government released the COVID-19 PEN to respond and to minimize the negative impact of COVID-19 on society. One of the PEN programs is to strengthen social protection programs. This program is vital since the pandemic resulted in the shrinking economy and increased poverty due to many people losing their jobs. The government released the social protection package consist of: conditional cash transfer, cash transfer for people living outside of Jabodetabek, village fund cash transfer, basic food assistance for people living in the urban area near Jakarta city (Jabodetabek), basic food voucher, electricity subsidy, and pre-work card, wage assistance, wage subsidy assistance for non-permanent teachers, and internet quota subsidy for education.

In the implementation process, the Indonesian government faces many challenges, and have to be adaptive and responsive to improve the social protection program quality and budget adequacy until the COVID-19 spread can be managed and minimalized. Several issues happen in the implementation, including corruption at the national and local levels, the accuracy of the beneficiary data, and benefit adequacy. At the first year of Covid, the 
Rizqi Haniyah, Fandy Anggara Putra, Indonesia Budget and Social Protection: Response to COVID-19 Pandemic

government seemed more focused on the speed of delivery of the program and traded off the accuracy of the targeting.

The government should take a corrective response to the issue. The distribution mechanism should be in the form of cash and transferred directly to the beneficiaries to minimize the risk of corruption. The beneficiary data need to be gradually improved by incorporating national and local government to share and improve the data quality. The government should find more sustainable funding resources or perform budget reallocations to ensure that social protection programs can be adequately funded without endangering macroeconomic stability.

\section{REFERENCES}

Akhlas, A.W., 2020. Indonesia's burden-sharing scheme may affect BI's credibility: Moody's. Jakarta Post.

Alfedo, J.M., Azmi, R.H.N., 2020. Sistem Informasi Pencegahan Korupsi Bantuan Sosial Si Pansos) di Indonesia: Rumusan Konsep dan Pengaturan. J. Antikorupsi 6, 283-296.

Ayu, R., 2020. Kemendikbud Alihkan Anggaran Ujian Nasional 2020 Untuk Penanganan Pandemi Corona (Ministry of Education and Culture shift Budget for National Exam to Pandemic COVID Response). Tribunnews.com 1-7.

Bardan, A.B., 2020. Bansos Sembako Diperpanjang Sampai Akhir Tahun, Semuanya Dikelola Kemensos. KONTAN.CO.ID.

Barroy, H., Wang, D., Pescetto, C., Kutzin, J., 2020. How to budget for COVID-19 response? World Heal. Organ. 1-5.

Bisnis Indonesia, 2021. Mid Year Economic Outlook 2021 [WWW Document].

Boin, A., Hart, P. 't, Kuipers, S., 2017. The Crisis Approach. In: Handbook of Disaster Research, Handbooks of Sociology and Social Research. Springer International Publishing AG, New York, pp. 23-38.

CMEA, 2020. Laporan Manajemen Pelaksana Program Kartu Prakerja Tahun 2020

(Management Report: Implementation of Pre-work Card 2020). Jakarta.

CMfHDC, 2021. Pengawasan Bansos 2021 Diperketat (Supervision of Bansos 2021 is Tightened) [WWW Document]. Coord. Minist. Hum. Dev. Cult.

Fahlevi, F., 2020. Kemensos di Era Juliari Tunjuk Langsung Penyedia Sembako Bansos , Ini Alasannya (The Ministry of Social Affairs Directly Appoints Bansos Staple Food Providers, This is the Reason). Tribunnews.com 12-15. 
Fitchratings, 2020. Fitch Affirms Indonesia at "BBB"; Outlook Stable [WWW Document]. Rat. Action Comment.

Fukuchi, A., 2020. Impact of COVID-19 on the Indonesian Economy and its Prospects. Inst. Int. Monet. Aff. 11, 1-18.

Gentilini, U., Almenfi, M., Dale, P., 2020. Social Protection and Jobs Responses to COVID-19: A Real-Time Review of Country Measures, World Bank.

Gumilang, P., 2020. Belanja Alutsista Terimbas Covid-19, Kemhan Atur Prioritas (Purchasing for Military Equipment Affected by Covid-19, the Ministry of Defense Sets Priorities). CNN Indones. 1-7.

Halim, D., 2020. Respons 3 Lembaga Penegak Hukum Setelah Anggarannya Dipotong untuk Atasi Covid-19 (Response of 3 Law Enforcement Institutions After Their Budgets Are Cut to Overcome Covid-19). Kompas.com 1-8.

Hanna, R., Olken, B., 2020a. Social Protection in the COVID-19 ERA: What can the evidence tell us?

Hanna, R., Olken, B., 2020b. Strengthening Indonesia 's social protection in the COVID-19 era : Strategy and lessons from evidence [WWW Document]. povertyactionlab.org.

Hidayat, A.N., 2020. Risiko Perpanjangan Burden Sharing (The Risk of Extending Burden Sharing). investor.id 4-6.

Horton, M., El-Ganainy, A., 2020. Fiscal Policy: Taking and Giving Away. IMF (Finance Dev. $1-4$.

Jõgiste, K., Peda, P., Grossi, G., 2012. Budgeting in a time of austerity: The case of the Estonian central government. Public Adm. Dev. 32, 181-195.

Kacaribu, F., 2020a. Menjaga Kelangsungan Ekonomi Indonesia dari Pandemi COVID-19 (Maintaining the Continuity of the Indonesian Economy from the COVID-19 Pandemic). Jakarta.

Kacaribu, F., 2020b. Social Protection Programs to Respond Pandemic. Jakarta. Khasiani, K., Koshima, Y., Mfombouot, A., Singh, A., 2020. Budget Execution Controls to Mitigate Corruption Risk in Pandemic Spending. Fisc. Aff. - Int. Monet. Fund 1-9. KPK, 2020. KPK Tahan Menteri Sosial Terkait Perkara Dugaan Suap Pengadaan Bansos Covid-19 (KPK Arrests Minister of Social Affairs Regarding Alleged Bribery Case for Covid-19 Social Assistance Procurement), Siaran Pers. Jakarta.

MoEC, 2021. Technical Instructions For Distribution Of Government Assistance Of Internet 
Rizqi Haniyah, Fandy Anggara Putra, Indonesia Budget and Social Protection: Response to COVID-19

Data In 2021 (Petunjuk Teknis Penyaluran Bantuan Pemerintah Paket Kuota Data Internet Tahun 2021). Jakarta.

MoF, 2020a. 2020 Government Budget Revision (Perubahan Postur APBN).

MoF, 2020b. Burden Sharing Pembiayaan Penanganan Pandemi Covid-19 antara Pemerintah dan Bank Sentral (Burden Sharing of Financing for Handling the Covid-19 Pandemic between the Government and the Central Bank), Pers Release.

MoF, 2020c. Program Kartu Sembako Kartu Sembako (Basic Food Voucher Program). Bandung.

MoF, 2021. 2020 Financial Report - The Government of Republic of Indonesia (Laporan Keuangan Pemerintah Pusat Tahun 2020 - Audited), 2020 Financial Report. Jakarta. MoNDP, 2020a. Laporan Perkembangan Ekonomi Indonesia dan Dunia Triwulan IV Tahun 2020 (Economic Development Report for Indonesia and the World Quarter IV 2020. Jakarta.

MoNDP, 2020b. Panduan Pendataan Bantuan Langsung Tunai - Dana Desa (Guidelines of data collection the recipient of Village Fund Cash Transfer). E-Book.

Nazara, S., 2020. Financing the Responses to COVID-19 Pandemic in Indonesia. Present. Crawford Sch. Public Policy.

Noerkaisar, N., 2021. Efektivitas Penyaluran Bantuan Sosial Pemerintah untuk Mengatasi Dampak Covid-19 di Indonesia. J. Manaj. Perbendaharaan 2, 83-104.

Oktari, R., 2020. Atasi Pandemi, Warga Non-Jabodetabek juga Dapat Bantuan Tunai (Overcoming the Pandemic, Non-Jabodetabek Residents Can Also Get Cash Assistance). indonesiabaik.id 1-5.

Olivia, S., Gibson, J., Nasrudin, R., 2020. Indonesia in the Time of Covid-19. Bull. Indones. Econ. Stud. 56, 143-174.

Premchand, A., 1983. Government Budgeting and Expenditure Controls: Theory and Practice, Journal of Money, Credit and Banking. International Monetary Fund, Washington DC.

Rahim, F., Allen, R., Barroy, H., Gores, L., Kutzin, J., 2020. COVID-19 Funds in Response to the Pandemic, IMF COVID-19 Special Series. Int. Monet. Fund.

Ramli, R.R., 2021. Mulai April 2021 , Pelanggan 450 VA Tak Lagi Dapat Listrik Gratis (Starting April 2021, 450 VA Customers will no longer receive free electricity). Kompas.com 17-19.

Statistics Indonesia, 2020a. Persentase Tenaga Kerja Informal Sektor Pertanian (Percentage 


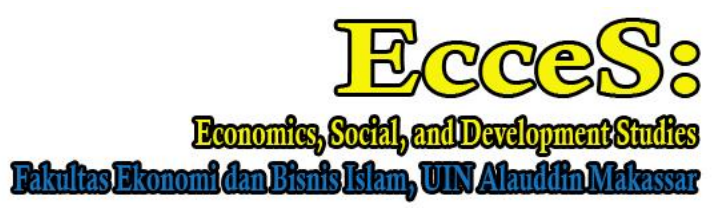

Volume 8 Number 2 Ed. December 2021: page:132-154 p-ISSN: 2407-6635 e-ISSN : 2580-5570

of Informal Labor in the Agricultural Sector) [WWW Document].

Statistics Indonesia, 2020b. Proporsi Lapangan Kerja Informal Sektor Non-Pertanian

Menurut Daerah Tempat Tinggal (Proportion of Informal Employment in the Non-

Agricultural Sector by Area of Residence) [WWW Document].

Teja, M., 2020. Permasalahan Keakuratan Data Penerima Bantuan Sosial Covid-19 (Issues of Accuracy of Recipients of COVID-19 Social Assistance). Info Singk. Kaji. Singk. terhadap Isu Aktual dan Strateg. Vol. XII, 13-18.

Una, G., Allen, R., Pattanayak, S., Suc, G., 2020. Digital Solutions for Direct Cash Transfers in Emergencies. Int. Monet. Fund 1-9.

UNCTAD, 2020. The coronavirus shock: a story of another global crisis foretold and what policymakers should be doing about it.

UNICEF, 2020. UNICEF Social Protection Response to COVID-19 Technical note. UNICEF for Every Child.

World Bank, 2020a. Overview: Reversals of Fortune, Poverty and Shared Prosperity 2020.

Washington DC.

World Bank, 2020b. Indonesia Monitoring of Impacts Highlights ( I ). Jakarta.

World Bank, 2021. Poverty \& Equity Brief: Indonesia.

Zahara, L., Andini, M.S., Wulandari, S., 2021. Referensi : Perkembangan Komposisi Belanja

Pemerintah Pusat Berdasarkan Fungsi, Jenis, dan Organisasi Tahun 2018-2021

(Development of Central Government Expenditure Composition based on Function, Type, and Organization in 2018-2021).

Zhacky, M., 2020. Alihkan untuk Penanganan Corona, KLHK Potong Anggaran Rp 1 , 5 T

(Divert for Handling Corona, KLHK Cut Budget IDR 1.5 Trillion). detik.com 4-5. 